\title{
Forest owner representation of forest management and perception of resource efficiency: a structural equation modeling study
}

\author{
Andrej Ficko $^{1}$ and Andrej Boncina ${ }^{1}$
}

\begin{abstract}
Underuse of nonindustrial private forests in developed countries has been interpreted mostly as a consequence of the prevailing noncommodity objectives of their owners. Recent empirical studies have indicated a correlation between the harvesting behavior of forest owners and the specific conceptualization of appropriate forest management described as "nonintervention" or "hands-off" management. We aimed to fill the huge gap in knowledge of social representations of forest management in Europe and are the first to be so rigorous in eliciting forest owner representations in Europe. We conducted 3099 telephone interviews with randomly selected forest owners in Slovenia, asking them whether they thought they managed their forest efficiently, what the possible reasons for underuse were, and what they understood by forest management. Building on social representations theory and applying a series of structural equation models, we tested the existence of three latent constructs of forest management and estimated whether and how much these constructs correlated to the perception of resource efficiency. Forest owners conceptualized forest management as a mixture of maintenance and ecosystem-centered and economics-centered management. None of the representations had a strong association with the perception of resource efficiency, nor could it be considered a factor preventing forest owners from cutting more. The underuse of wood resources was mostly because of biophysical constraints in the environment and not a deep-seated philosophical objection to harvesting. The difference between our findings and other empirical studies is primarily explained by historical differences in forestland ownership in different parts of Europe and the United States, the rising number of nonresidential owners, alternative lifestyle, and environmental protectionism, but also as a consequence of our high methodological rigor in testing the relationships between the constructs. We suggest developing natural resource management concepts that emphasize forests not just as ecosystems, but as socialecological systems.
\end{abstract}

Key Words: attitudes; conceptualization; management concepts; natural resources; private forest owners; social representations theory; timber supply; values

\section{INTRODUCTION}

In contrast to the continual decline of forests globally (FAO 2010), European forests have been expanding since the middle of last century (Gold et al. 2006). Current resource conditions indicate their underuse in the past; the ratio of fellings to increment has declined from $90 \%$ in 1950 to $55 \%$ currently (Nabuurs et al. 2007). Future projections of the availability of timber from European forests show that if current management practices continue, timber supply may increase further for the next 50 years (Nabuurs et al. 2007). The timber supply potential and constraints in extraction have been acknowledged in several policy documents, e.g., the European Union (EU) Forest Action Plan (Commission of the European Communities 2006). The European Commission, while raising the target for renewable energy resources to $20 \%$ of overall energy consumption by 2020 , underlined that the availability of woody biomass should be taken into account (European Parliament, Council of European Union 2009). Many estimations of the potential (e.g., Nabuurs et al. 2007) and realizable supply of woody biomass (Mantau et al. 2010, Verkerk et al. 2011) have emphasized the importance of social factors that may constrain timber supply. Given the fact that in the EU private forests prevail and that most of the individual- or family-owned forests in the EU are small scale (Schmithüsen and Hirsch 2010) and many private forest owners show strong nonmaterialistic attitudes toward their forests (e.g., Dhubháin et al. 2007), the willingness of private forest owners to provide timber is likely to be one of the key drivers in the mobilization of wood resources in the EU. Many studies on the social availability of timber from the United States provide evidence on the significance of owner attitudes toward harvesting on timber availability (e.g., Butler et al. 2010, Markowski-Lindsay et al. 2012).

Whenever social factors have been considered in the projections of timber supply, they have been exclusively included as manifest variables, such as socio-demographic characteristics of forest owners or stated ownership objectives (e.g., Max and Lehman 1988, Verkerk et al. 2011). A significant body of private forest ownership literature on owner attitudes, beliefs, objectives, and motivations shows that a substantial share of private forest owners manage their properties for noncommodity objectives (Dhubháin et al. 2007), which do not always correlate with sociodemographic parameters (e.g., Ficko and Boncina 2013). Moreover, there is a lack of empirical studies on whether the harvesting behavior of private owners correlates to a specific representation of forest management that might differ from the scientific representation of forest management. Questions such as what forest owners understand by forest management and whether and how much their representation of forest management influences their perception of resource efficiency have never been studied in Europe on a national scale using social psychology theories and statistical methodologies that take a hypothesistesting approach. Our research is the first of its kind in the relatively wide body of private forest ownership literature in Europe that studies the theoretical constructs of forest management and resource efficiency among private forest owners using a series of structural relation equations between the abstract 
phenomena and their indicators. The differences in the conceptualization of forest management between private forest owners and natural resource professionals may become crucial for the implementation of sustainable forest management in the era of rapidly changing forest ownership from traditional types to new owner types (Hogl et al. 2005).

The rationale for looking beyond the level of private forest owner management objectives is provided within the social representations theory of Moscovici (2008). The theory claims that the beliefs, attitudes, or emotions of a social group constitute the social group-specific representation of reality. It implies that there is no objective world, but the perceived, framed into mental models that represent an internal representation of external reality (Jones et al. 2011). In the view of the social representations theory, any concept, e.g., forest management or efficiency, may be understood differently by different individuals and different social groups. The theory implies that the representations of social group members are similar and can be elicited by different techniques (Jones et al. 2011). Recently, Lynam et al. (2012) provided a synthesis of tools and processes needed to elicit and analyze mental models in human-environment relationships. They concluded that despite the high diversity of meanings associated with mental models, the core elements of social representations are consensual and relatively stable. Social representations of a social group should be interpreted within the framework of existing knowledge structures and always take into consideration the context and the attributes of the individuals of the group (Lynam et al. 2012). Thus, forest owner behavior may be interpreted as the result of their representation of forest management, which consists of values, beliefs, and attitudes in a value-attitude-behavior hierarchy (Homer and Kahle 1988; left side of the Fig. 1) processed in a cognitive system referred to as mental model (Lynam et al. 2012; right side of the Fig. 1).

There is an increasing amount of empirical evidence on different representations of environmental issues by different social groups in Europe, the key groups being scientific communities, e.g., natural resource professionals; policy makers, e.g., governments; and stakeholders, e.g., citizens; see, for example, Hovardas and Stamou (2006), Fischer et al. (2011), Buijs et al. (2012), and Buijs and Elands (2013). However, there is a huge gap in our knowledge of social representations of forest management, particularly with respect to private forest owner representation. This seems to be less the case for the United States. Kearney and Bradley (1998) and Kearney et al. (1999) investigated how U.S. Forest Service employees, timber company employees, and environmentalists, but not forest owners, conceptualize human dimensions of forest management and its content. Rickenbach et al. (1998) examined the adoption of an ecosystem-based forest management concept among private forest owners in Massachusetts and found a positive attitude toward it. Belin et al. (2005) conducted a similar study on the receptivity of private forest owners to an ecosystembased approach to management in the northern United States using the same measurement instrument as Rickenbach et al. (1998). Although both studies investigated the adoption of a single management concept defined in advance and thus cannot be treated as social representations studies, they provide important insights on the attitudes of forest owners toward one forest management paradigm. Erickson et al. (2002) explored forest owner approaches to forest management in the midwestern
United States by asking them to indicate how well each of the several proposed activities describe the management on their properties. Steiner Davis and Fly (2010) conducted another quantitative empirical study on forest owner conceptualization of forest management. However, like the study of Erickson et al. (2002), this study also referred to the United States, which might make it difficult to use these as benchmark studies for research in other cultural contexts. Moreover, Steiner Davis and Fly (2010) did not quantify the magnitude of the relation between nonuse value-related representations of forest management and harvesting behavior.

Fig. 1. Simplified conceptual model of forest owner representation of forest management influencing harvesting behavior; mental model adapted from Lynam et al. (2012), complemented with the value-attitude-behavior hierarchy.

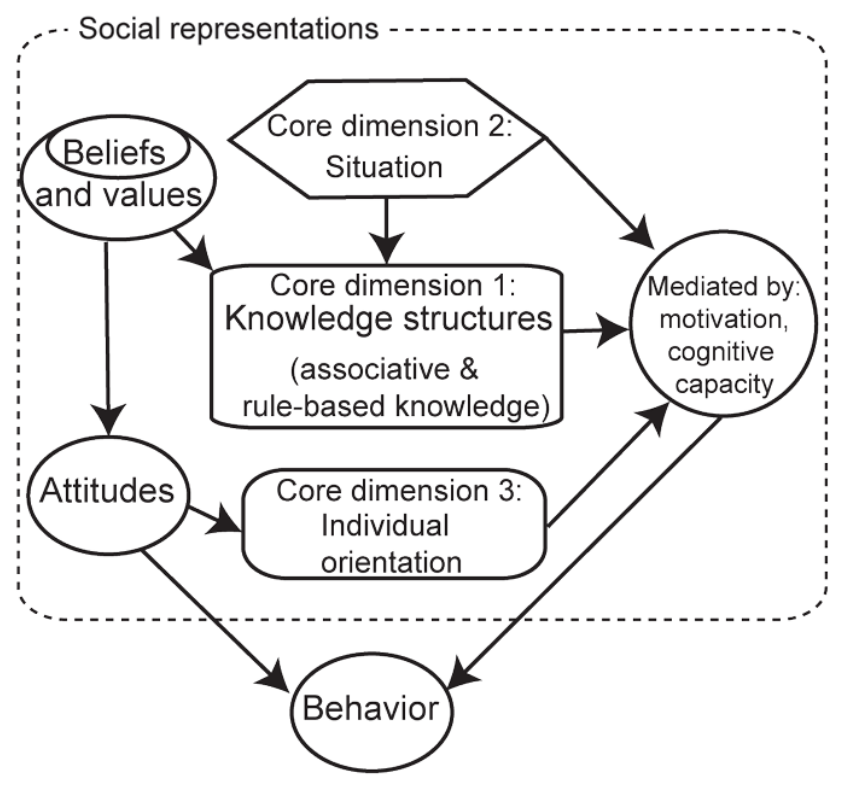

Recently, Lawrence and Dandy (2014) reviewed predominantly "grey literature" in the United Kingdom in the field of values, beliefs, and attitudes of private forest owners. They concluded that there is variability in the representation of management among forest owners and contrast between the official perception of undermanaged forests and owner beliefs that appropriate forest management was being undertaken. However, Lawrence and Dandy (2014) did not provide empirical evidence on forest owner representation of forest management.

Bearing in mind the lack of quantitative research on social representations of forest management in Europe, our aims were (1) to provide empirical evidence on forest owner representation of forest management using social representations theory and a confirmatory approach to the analysis of the forest management construct; (2) to identify the biophysical and conceptual constraints in timber supply perceived by private forest owners; and (3) to verify and quantify the association between forest owner representation of forest management and their perception of resource efficiency and the perceived cutting constraints. 


\section{METHODS}

\section{Study area}

We interviewed Slovenian forest owners as an example of smallscale nonindustrial private forest owners. In Slovenia, $77 \%$ of forests are privately owned (Medved et al. 2010). Most private forests have been in the possession of natural persons for generations, typically farmers and their family members, and are $<3$ ha on average. The proportion of family farms has decreased from $64 \%$ in the 1950 s to $30 \%$ currently (Medved et al. 2010). Owners with $<1$ ha represent $67.5 \%$ of owners but control merely $9 \%$ of private forests. The forest property size structure $>1$ ha is $71.9 \%, 21.9 \%, 4.7 \%$, and $1.6 \%$ of forest owners in size classes $1-4.9$ ha, 5-14.9 ha, 15-30 ha, and >30 ha of forestland, respectively. For most farmers and nonfarmers, the forest is not their main source of income. The realized supply of wood from private forests has declined to on average $65 \%$ of the allowable cut. Roundwood production from family farms has gradually decreased in the last 10 years, whereas fuelwood production has increased. Forest owners do the work mostly by themselves. Business models such as long-term property lease, harvesting leasing, cooperatives, or contracting are still scarce. "Close-tonature" forestry has been the traditional approach to forest management in Slovenia for more than a century. It focuses primarily on the ecological dimension of sustainability. The clearcutting of forests is prohibited. Property rights are limited by public interest and by the obligation to take into account multiple functions of the forests.

\section{Sampling design}

We set a target number of 1000 responses to achieve an acceptable margin of sampling error of $\pm 3.0 \%$ (Krejcie and Morgan 1970), to fit our budget constraints, and to get a sample of sufficient size for statistical analyses with large sample techniques. To approach the required sample size, we conducted 3099 telephone interviews with randomly selected private forest owners owning at least 1 ha of forestland. The selection of the candidates was stratified by property size to match the forest property size structure $>1$ ha at the national level (Medved et al. 2010).

Forest owners were surveyed from September 23 to 27, 2013, after $4 \mathrm{PM}$, using computer-aided telephone interviewing. An average interview lasted $6.25 \mathrm{~min}$ ( $\pm 2.37 \mathrm{~min}$ ). Of the 3099 interviewees, 969 claimed to be nonowners $(31.3 \%) ; 1074(34.7 \%)$ were unreachable at the time of the call, i.e., each owner was called 6 times before being considered nonrespondent; and 2 were unaware of owning a forest, which resulted in a realized sample of 1054 forest owners. Without data imputation, the number of 1054 interviews would have eventually decreased to 701 because of item nonresponse to 2 major questions (Q2 and Q3, Appendix 1). Therefore, for all cases in which one of the items of $Q 2$ and Q3 was missing, we used a multiple imputation technique after we checked graphically that the missing values exhibited a random pattern. Altogether, we imputed $0.19 \%$ of all responses. Given the negligible percentage of imputed values, we did not perform a sensitivity analysis. Eventually, the number of observations with imputation reached 754. Before all further analyses, we used case weights to fine-tune the sample to the population because of the slight overrepresentation of owners with smaller properties.

Representativeness of the sample was checked by inspecting the spatial distribution of respondents and nonrespondents and by comparing their socio-demographic variables. We found that both respondents and nonrespondents were randomly distributed across the country and that they mostly came from the same places (Cramer's V for the association between the places of residence of respondents and nonrespondents $=0.798, \mathrm{P}<0.01$ ). Respondents did not differ significantly from nonrespondents in their age (61.1 vs. 61.4 years) and number of parcels per forest property (13.6. vs. 12.4; an independent samples t test, $\mathrm{P}>0.05$ level), and male/female ratio was $1: 2$ in both groups (a 2proportion $\mathrm{z}$ test, nonsignificant).

\section{Survey design}

First, the interviewees were asked in the form of a closed-ended question whether they thought they managed their forest property efficiently (Q1). They were given a choice among five answers: (1) affirmative, reporting efficient management; (2) negative, reporting underuse of wood resources; (3) negative, reporting overuse of wood resources; (4) ambivalent, reporting indecision; and (5) no management, no cut. The respondents who reported efficient management $(\mathrm{Q} 1=1)$ were labeled as the self-perceived efficient owners, hereinafter "efficient" owners. Those reporting underuse or no management $(\mathrm{Q} 1=2$ or 5$)$, the self-perceived inefficient owners, hereinafter "inefficient" owners, were instructed to rate the importance of 17 items indicating possible reasons for underuse (Q2, q2_1 to q2_17, Appendix 1) using a five-point Likert scale, (1) being not at all important and (5) being very important.

The survey continued with the question of what they understood by forest management (Q3, Appendix 1). The respondents were provided with statements defining forest management (q3_1 to q3_19) and asked to indicate their level of agreement on a fivepoint Likert scale. When formulating the statements, we partly adopted the definitions provided in an empirical study of social construction of forest management in Tennessee, USA (Steiner Davis and Fly 2010), but edited and merged them to fit the national context and simplicity required for telephone interviews. For instance, we dropped the definition "using pesticides to keep insects from harming plants or trees" (Steiner Davis and Fly 2010:323) because the use of pesticides in forests is prohibited in Slovenia. We also included statements that resembled owner management objectives recognized in private forest owner typologies (Dhubháin et al. 2008, Urquhart et al. 2012), assuming substantial association between individual representation of forest management and his or her behavior.

\section{Constructing baseline models}

The baseline model for the identification of cutting constraints (model 1, Fig. 2a) was a confirmatory factor analysis model. The number of cutting constraints and the hypothesized loadings of the items on them were based on past studies of management constraints in private forests in Slovenia (Tavcar and Winkler 2005, Veselic et al. 2010). Accordingly, we hypothesized the existence of three cutting constraints (F1, F2, and F3) and related them to the items that we considered their indicators (q2_5 to q2_17, Appendix 1). The cutting constraints were not allowed to correlate because they are intended to represent major, uncorrelated factors preventing forest owners from cutting more. We had no theoretical reasons for allowing the cross-loading of the items or the correlation of residuals (E2_1 to E2_17); items considered to measure only cutting constraints and none of the 
Fig. 2. Path diagrams for the hypothesized structural equation models for the estimation of (a) factors preventing forest owners from cutting more, i.e., cutting constraints F1, F2, and F3; (b) forest owner representations of forest management, i.e., F4, F5, and F6; (c) differences in factor means between the efficient and inefficient owners, means and covariance structures model (MACS); (d) association between the cutting constraints and the representation of forest management (dotted two-headed arrows). The parameters to be estimated are denoted with an asterisk $\left(^{*}\right)$. In each model, one path per factor was fixed to 1 for identification purposes. Measured variables and factors are represented by squares and ellipses, respectively. Regression-like error terms are represented with E. Disturbance terms for factors in MACS are represented with D. Single-headed arrows indicate the hypothesized causal relationship between two variables; two-headed arrows indicate correlation. The explanation of other symbols in MACS is provided in Methods.

(a)
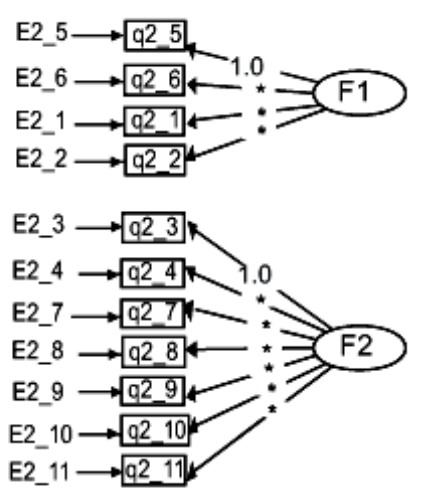

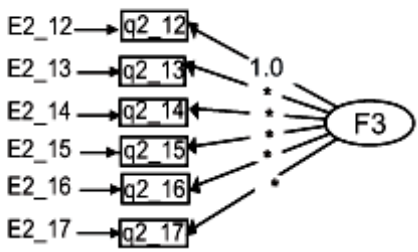

(c)

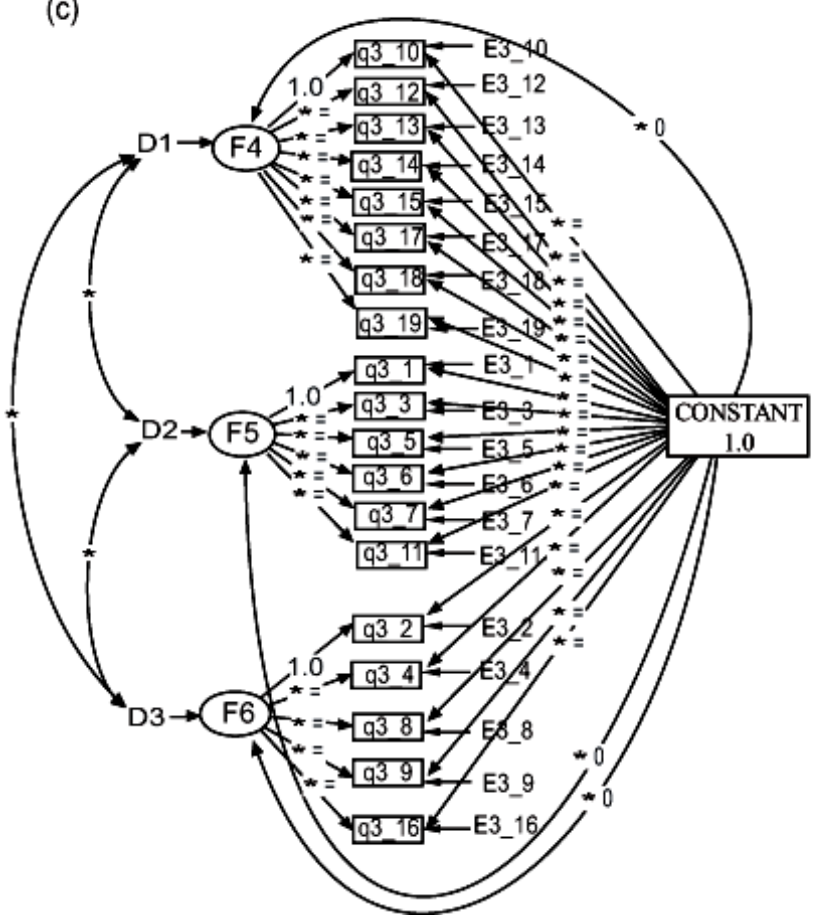

(b)

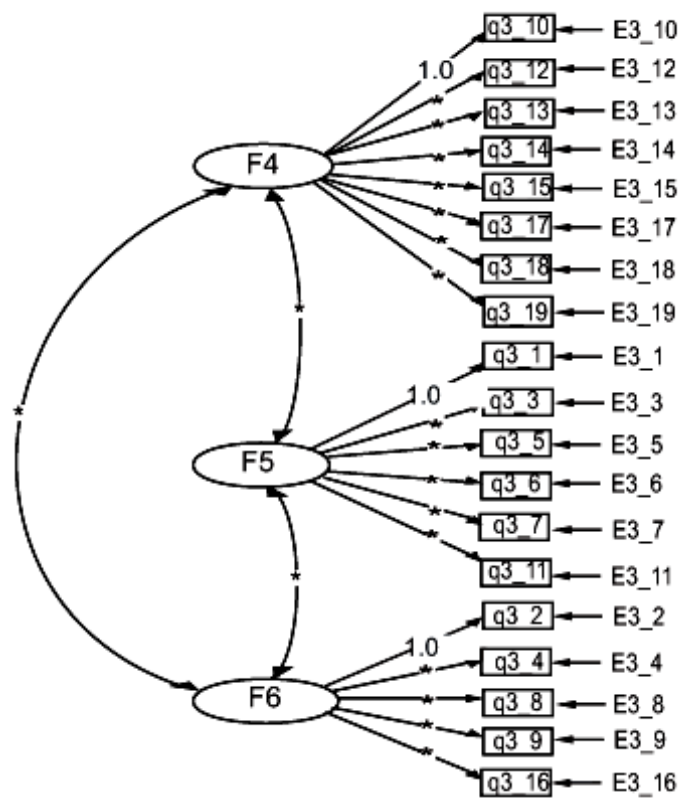

(d)

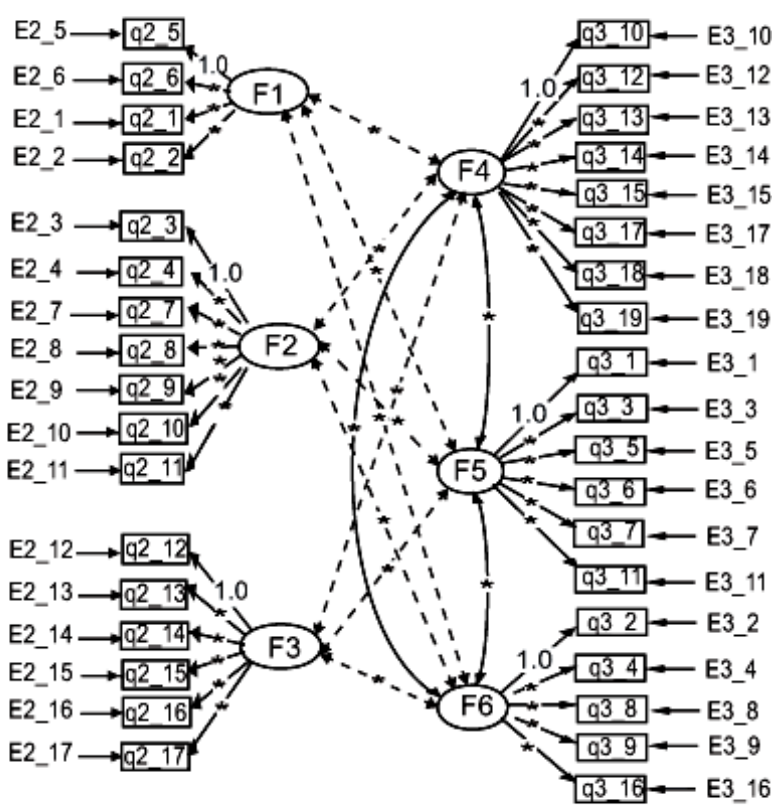


combinations of the items were expected to measure constructs other than the one specified in the model. Review of the Lagrange multiplier statistics suggested adding several parameters to improve the model. However, the respecification yielded only trivial improvement of model fit, and there was no theoretical justification for post hoc modifications. Hence, we set the hypothesized model (Fig. 2a) as the baseline model for the identification of cutting constraints (cf. Savalei and Bentler 2006).

The baseline model for the identification of forest owner representation of forest management (model 2, Fig. 2b) was a structural equation model constructed for the group of efficient owners first. Based on the study of Steiner Davis and Fly (2010), which found three conceptualizations of forest management among private forest owners and related literature on private forest owner attitudes to forests (see Introduction), we tested the hypothesis that forest owners conceptualize forest management in three different ways (i.e., F4, F5, and F6) and that these concepts manifest through agreement with the statements from q3_1 to q3_19 (Appendix 1). We allowed F4, F5, and F6 to correlate because cognitive constructs are complex and are likely to overlap in their content (e.g., Vaske et al. 2001).

Upon evidence of adequate model 2 fit in the group of efficient owners, the construct validity was tested in the group of inefficient owners. Since model 2 fits adequately to both groups, we used it as a baseline model for the identification of forest owner representation of forest management and proceeded with the test of invariance of representations between efficient owners and inefficient owners.

Testing the invariance in the representation of forest management Differences in the representation of forest management between the efficient and inefficient owners were tested in several steps (Bryne 2006). First, we established the configural model, which incorporated the single-group baseline models, i.e., model 2 , into a multigroup model, yet without cross-group constraints on the equality of parameters. In the configural model, we allowed the parameters of the multigroup model to be estimated for both groups independently, but simultaneously, and estimated fit statistics for the multigroup model. The configural model served as a baseline model against which the subsequently specified, structural invariant model was compared. By setting equality constraints on factor loadings and factor correlations across groups, we tested whether model 2 is structurally invariant in both groups.

In testing the invariance of groups when using models that are subsets of each other (nested models), we followed both a traditional and a recent approach. In the traditional approach, two models are equivalent if the difference between the $\chi^{2}$ values associated with the models ( $D$ test) is nonsignificant at the degrees of freedom calculated as the difference between the degrees of freedom associated with the models. Because of multivariate nonnormality of the data, the Satorra-Bentler scaled $\chi^{2}\left(\Delta \mathrm{S}-\mathrm{B} \chi^{2}\right)$ difference statistics (Satorra and Bentler 1988, 1994) were used instead of the D test. The recent approach is based on two criteria: the multigroup model still fits adequately, and the difference between the values of comparative fit index $(\Delta \mathrm{CFI})$ is $\leq 0.01$ (Cheung and Rensvold 2002). Because results of invariance tests are frequently contradictory (see Bryne 2006:249), our evaluation of the differences in the representation of forest management between efficient and inefficient forest owners is descriptive rather than statistically inferential.

\section{Testing the invariance of latent factor means}

Because concepts are unobservable, the conventional testing of significant differences in factor means between the groups is not possible. However, by applying the mean and covariance structures model (Sörbom 1974) in which the intercept variable is introduced and several intra- and cross-group constraints on factor loadings, loadings of the intercept variable on factors, and indicator variables are imposed (Fig. 2c), testing for factor mean differences is possible in a multigroup model. After the factor loadings were constrained to be equal across groups (marked with "*=", except for the loadings fixed to 1 for identification purposes), all intercepts for the indicator variables were constrained to be equal across groups (marked with "*="), and all factor intercepts were constrained to zero in the group of efficient owners, i.e., the reference group, but freely estimated in the other group (marked with "*0"), differences in latent factor means between the groups were estimated in a relative sense. By comparing the parameters in the construct equations, we estimated how much the mean of factors F4, F5, and F6 from the group of inefficient owners differs from the mean of the same factors from the reference group, which always equals zero given the previously mentioned constraints. A full description of the procedure is provided in Bryne (2006:261-292), and a more detailed theoretical background can be found in Bentler (2006:203-222).

\section{Testing for association between representations of forest management and cutting constraints}

To test for the association between representations of forest management and perceptions of cutting constraints, we established model 21 (Fig. 2d) in which we combined model 2 and model 1 by adding the correlation paths between the factors from both models. If the representation of forest management has a significant impact on the perception of cutting constraints, then the correlation between owner representation of forest management and cutting constraints should be high and significant. For instance, if the nonintervention concept is responsible for the underuse of wood resources in private forests, then the correlation between the factor resembling this concept and the perceived cutting constraints from model 1 should be high and significant. In contrast, if the underuse of wood resources is mostly because of factors other than the conceptual, no correlations between owner perception of cutting constraints and their representation of forest management should occur.

\section{Estimation procedure}

We used the maximum-likelihood estimation method to test the validity of the described structural equation models. Given the evidence of multivariate kurtosis, i.e., Mardia's (1970) normalized estimates of 50.91 for efficient and 6.30 for inefficient owners, we based all tests on robust statistics (Satorra and Bentler 1988, 1994). In the goodness-of-fit estimation, we report the standardized root mean-square residual (SRMR) along with fit indices (Hu and Bentler 1995). A rule of thumb is that the SRMR should be $<0.05$ for a good fit ( $\mathrm{Hu}$ and Bentler 1995), whereas values $<0.10$ may be interpreted as acceptable for social science studies (Hair et al. 1998). Among fit indices, we used the CFI 
Fig. 3. (a) Forest owner representations of forest management: maintenance forest management (MAINT), ecosystem-centered management (EM), and economics-centered management (ECON). Standardized parameters reported for efficient owners, in parentheses for inefficient owners. (b) Factors preventing forest owners from cutting more: conceptual constraints (CONCEP), physical constraints (MINOR), and potentially removable constraints (MAJOR). All parameters significant at $\mathrm{P}<0.05$.

(a)

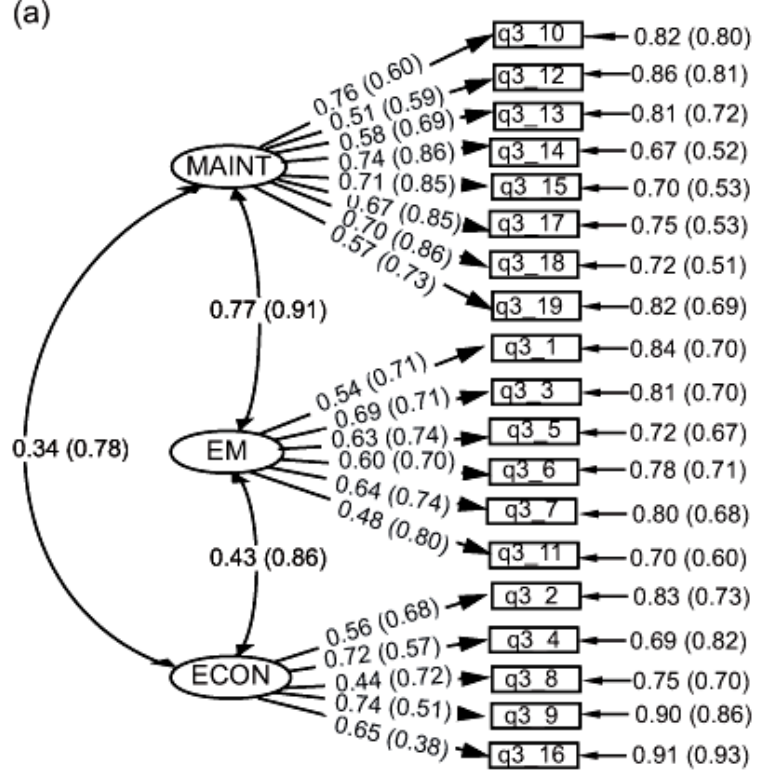

(b)

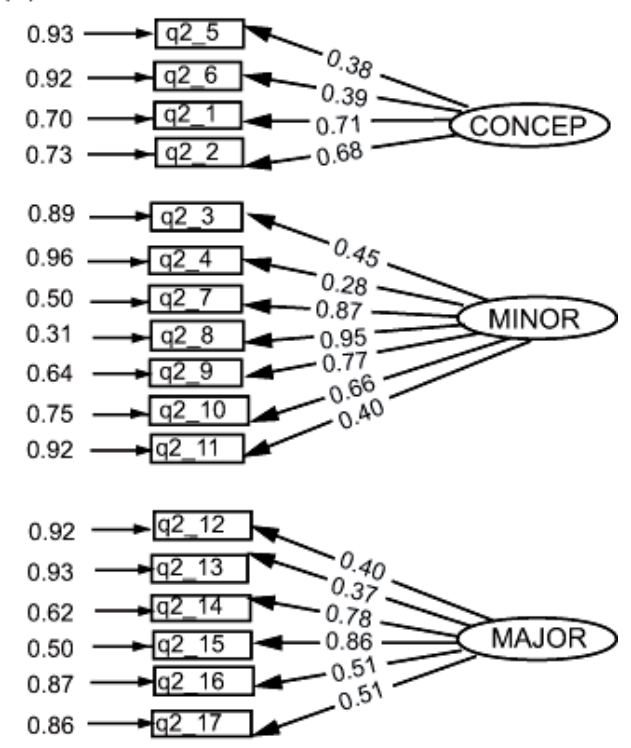

(Bentler 1990) and the Steiger-Lind root mean-squared error of approximation (RMSEA; Steiger 1990). An indication of adequate model-data fit is given when $\mathrm{CFI} \geq 0.90$ (Hu and Bentler 1999) and RMSEA $\leq 0.08$ (McDonald and Ho 2002); the cutoff values for good fit are CFI $\geq 0.95$ and $\mathrm{RMSEA} \leq 0.06$.

Multiple imputation and scale reliability assessment were performed in SPSS 21 (StatSoft 2013); all structural equation modeling was performed in EQS 6.2 (Bentler 2006). We report standardized parameter estimates obtained after analyzing the correlation matrices.

\section{RESULTS}

Forest owner representation of forest management

We found that private forest owners conceptualize forest management in three different yet overlapping ways (Fig. 3a). The most adopted representation of forest management can be described as maintenance forest management (MAINT). Definitions with the highest loadings on this factor include the following: forest management emphasizes the continuation of work started by ancestors (q3_10), ensuring a clean and natural environment in the neighborhoods (q3_14), preserving largediameter trees and removing low-quality trees (q3_15), and taking care of the forest so it is not left in a state of neglect (q3_18). The second representation can be referred to as ecosystem-centered management (EM). EM manifests as making decisions on what, when, and how a particular forest stand should be managed (q3_3), preserving the forest for future generations (q3_7), and caring for forest health and preventing diseases (q3_5). The third representation is labeled economics-centered management
(ECON), indicated by five definitions emphasizing the economic aspects of forest management (q3_2, q3_4, q3_8, q3_9, and q3_16). The overlap of forest management representations is substantial, particularly between MAINT and EM, which indicates that MAINT incorporates many aspects of EM. However, the concepts cannot be merged; a two-factor model with MAINT and EM merged and the ECON concept fit inadequately $(\mathrm{CFI}=0.896, \mathrm{RMSEA}=0.100, \mathrm{SRMSR}=0.075)$.

Efficient and inefficient forest owners conceptualize forest management in a similar way, yet the hypothesized structure of the forest management construct fits slightly better to inefficient (Table 1). The goodness of fit was also acceptable in multigroup testing; see goodness of fit of the configural model in Table 2. Thus, we confirmed that the number of representations of forest management and measurement variables used to identify them are equal in both groups. However, testing for the equality of factor loadings and factor correlations between efficient and inefficient owners, i.e., structural invariance, yielded slightly contradictory results, depending on the criteria used for the determination of invariance. If adhering to the traditional approach, we should conclude that factor loadings and factor correlations do not operate equally across both groups $\left(\Delta \mathrm{S}-\mathrm{B} \chi^{2}\right.$ $=120$ at $\mathrm{df}=19, \mathrm{P}<0.05)$. If adhering to the recent approach, we may conclude that efficient and inefficient owners conceptualize forest management with three structurally invariant concepts; the structural invariant model still fits adequately (CFI $=0.924)$ to both groups, and the drop in model fit between the configural and structural invariant model is negligible $(\Delta \mathrm{CFI}=0.01$, Table 2$)$. 
Fig. 4. Correlations between forest owner representations of forest management (MAINT, EM, and ECON) and perceived cutting constraints (CONCEP, MINOR, and MAJOR) shown as two-headed dashed arrows. All parameters significant at $\mathrm{P}<0.05$. MAINT $=$ maintenance forest management $\mathrm{EM}=$ ecosystem-centered management; ECON = economics-centered management; CONCEP = conceptual constraints; $\mathrm{MINOR}=$ physical constraints; MAJOR = potentially removable constraints.

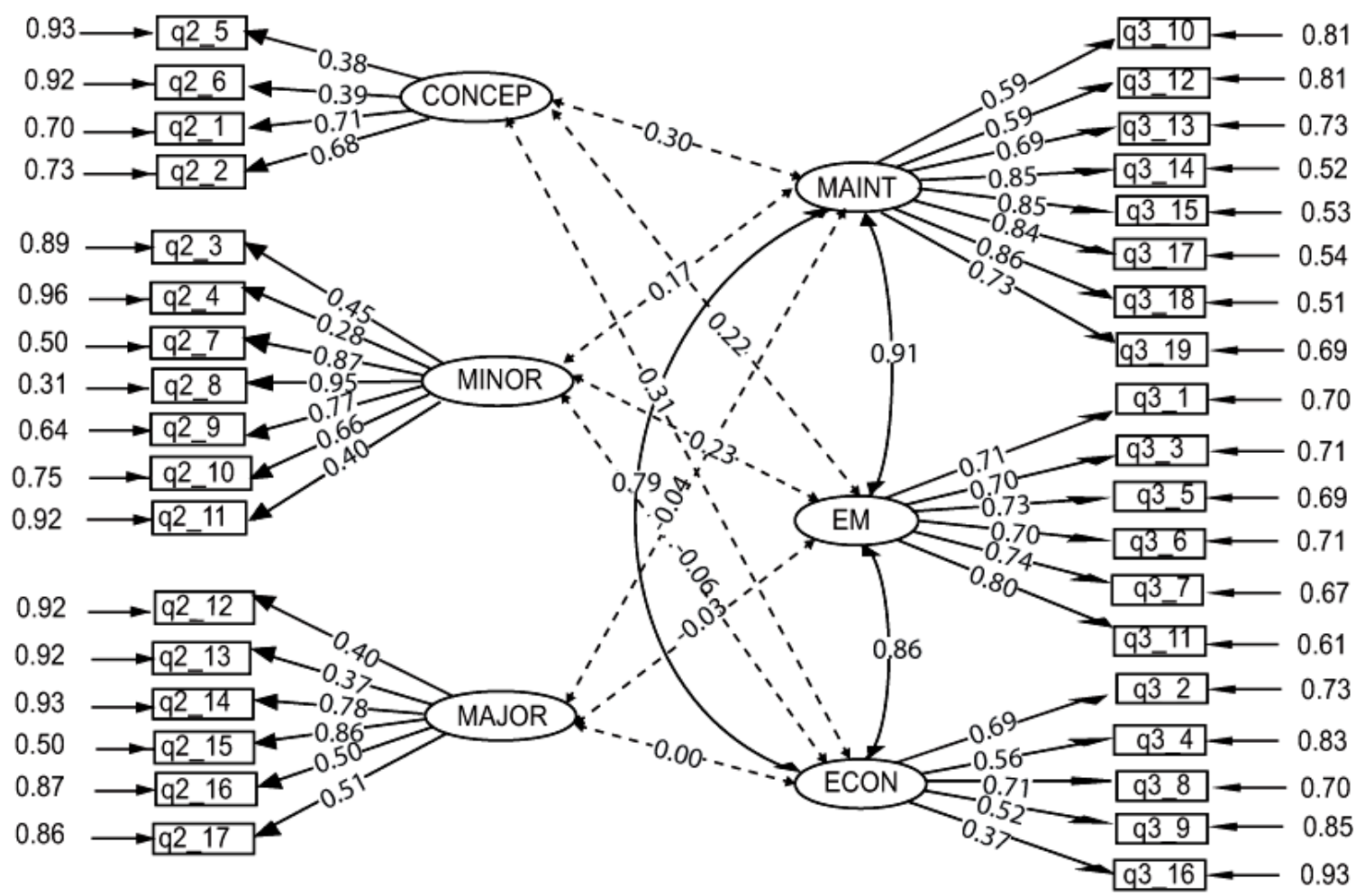

\section{Adoption of a certain representation of forest management}

The level of adoption of a certain concept differs between efficient and inefficient owners. As the factor intercepts in forest management representation equations show (Table 3), inefficient owners do not adopt on average the MAINT and EM concepts as much as efficient owners, whereas we found no significant difference between them in the adoption of the ECON concept. The mean values of the MAINT and EM concepts were lower by an average of 0.342 and 0.169 , respectively (Table 3 ).

\section{Perception of resource efficiency and cutting constraints}

Almost 87\% $(n=651)$ of the surveyed forest owners perceived themselves as efficient and that they should not cut more. None of the respondents reported overuse of wood resources or was ambivalent. Factors preventing the inefficient owners $(n=103)$ from cutting more can be adequately represented (CFI $=0.90$, RMSEA $=0.09$, SRMSR $=0.100$ ) with three cutting constraints (Fig. 3b), presented in order of decreasing percentage of variance explained: (1) physical constraints in forest work, dissatisfaction with the timber market, and lack of skills (22.0\% of variance), which can be overcome through education, better equipment, and higher market prices and are therefore labeled as MINOR; (2) potentially removable constraints, which are harder to overcome, e.g., unmarked boundary lines, ignorance of parcel locations, and lack of time to manage $(16.5 \%)$, labeled as MAJOR; and (3) constraints of a conceptual nature, which are thus relatively noncontrollable (12.5\%), labeled as CONCEP. MINOR and MAJOR accounted for most of the explained variance, indicating that underuse of wood resources in private forests in Slovenia is mostly because of biophysical factors, either minor or major, rather than a consequence of no need for wood or income from the forest or other objective circumstances.

\section{Representation of forest management and perceived cutting} constraints

None of the correlations between forest management representations and cutting constraints were substantial $(\mathrm{r} \leq 0.31$, $\mathrm{P}<0.05$, Fig. 4), suggesting that forest management representations cannot be considered an important driver for underuse of wood resources. The specific hypothesis that the nonintervention forest management concept could explain low cutting intensities in private forests was not confirmed. Although the correlations between the conceptual constraints (CONCEP) and forest management representations were the highest among all correlations, the correlation between EM and CONCEP was no stronger than the correlations between CONCEP and other cutting constraints at the same probability level $(r=0.22, r=0.30$ for CONCEP-MAINT and CONCEP-ECON, respectively, $\mathrm{P}<$ $0.05)$. We found no significant correlation between factor MAJOR and forest management representations $(r=0.00,-0.03$, and -0.04 , for MAJOR-ECON, MAJOR-EM, and MAJOR- 
Table 1. Goodnes-of-fit statistics of the model of forest owner representations of forest management (model 2) for efficient $(n=651)$ and inefficient $(n=103)$ owners, and the model of association between the representation of forest management and cutting constraints (model 21). CFI = comparative fit index; RMSEA = root mean-squared error of approximation; SRMR = standardized root mean-square residual.

\begin{tabular}{|c|c|c|c|c|c|c|c|c|c|c|}
\hline \multirow[b]{2}{*}{ Group } & \multicolumn{4}{|c|}{ Model 2} & \multicolumn{4}{|c|}{ Model 21} & \multicolumn{2}{|c|}{$\begin{array}{c}\text { Model } 2 \text { vs. } \\
\text { Model } 21\end{array}$} \\
\hline & CFI & $\chi^{2}(\mathrm{df})$ & RMSEA & SRMR & CFI & $\chi^{2}(\mathrm{df})$ & RMSEA & SRMR & $\Delta \mathrm{CFI}$ & $\begin{array}{c}\Delta \chi^{2} \\
(\Delta \mathrm{df})\end{array}$ \\
\hline $\begin{array}{l}\text { "Efficient" } \\
\text { owners }\end{array}$ & 0.923 & $\begin{array}{l}8393 \\
(149)\end{array}$ & 0.085 & 0.069 & $\mathrm{~N} / \mathrm{A}^{\dagger}$ & N/A & N/A & N/A & N/A & N/A \\
\hline $\begin{array}{l}\text { "Inefficient" } \\
\text { owners }\end{array}$ & 0.948 & $\begin{array}{l}3370 \\
(149)\end{array}$ & 0.103 & 0.076 & 0.857 & $\begin{array}{c}11064 \\
(582)\end{array}$ & 0.079 & 0.123 & 0.127 & $\begin{array}{c}7636 \\
(433)^{*}\end{array}$ \\
\hline
\end{tabular}

${ }^{\dagger}$ N/A not applicable to "efficient" owners.

$¥$ The Satorra-Bentler scaled $\chi^{2}$ difference (Satorra and Bentler 1988, 1994) is used due to multivariate non-normality.

* Significant at $\mathrm{P}<0.05$

Table 2. Testing the invariance in the representation of forest management between efficient and inefficient forest owners. CFI = comparative fit index; RMSEA = root mean-squared error of approximation; SRMR = standardized root mean-square residual.

\begin{tabular}{|c|c|c|c|c|}
\hline & \multicolumn{4}{|c|}{ Goodnes-of-fit statistics } \\
\hline & CFI & $\chi^{2}(\mathrm{df})$ & RMSEA & SRMR \\
\hline $\begin{array}{l}\text { Configural model: no equality } \\
\text { constraints }\end{array}$ & 0.934 & $11977(298)$ & 0.088 & 0.073 \\
\hline $\begin{array}{l}\text { Structural invariant model: factor } \\
\text { loadings and correlations equal }\end{array}$ & 0.924 & $13829(317)$ & 0.083 & 0.139 \\
\hline \multirow[t]{2}{*}{ "Efficient" vs. "Inefficient" } & $\Delta \mathrm{CFI}$ & $\begin{array}{c}\Delta \chi^{2} \\
(\Delta \mathrm{df})\end{array}$ & & \\
\hline & 0.01 & $120(19)^{*}$ & & \\
\hline
\end{tabular}

* Significant at $\mathrm{P}<0.05$

Table 3. Testing for differences in the adoption of the MAINT, EM, and ECON concepts between inefficient and efficient owners (reference group) with mean and covariance structure analysis (MACS). Values besides the constant (V999) in the construct equations are factor intercepts and represent concept means. Concept means in reference group are always zero. MAINT = maintenance forest management; $\mathrm{EM}=$ ecosystem-centered management; $\mathrm{ECON}=$ economics-centered management.

\begin{tabular}{lcc}
\hline \hline & $\begin{array}{c}\text { Test group: } \\
\text { "Inefficient” owners }\end{array}$ & $\begin{array}{c}\text { Reference group: } \\
\text { "Efficient" owners }\end{array}$ \\
\hline Construct equation & MAINT $=-0.342 * \mathrm{~V} 999+1.000 * \mathrm{D} 1$ & MAINT $=1.000 * \mathrm{D} 1$ \\
Standard error & 0.059 & \\
Robust test statistics & $-5.766^{*}$ & $\mathrm{EM}=1.000 * \mathrm{D} 1$ \\
Construct equation & $\mathrm{EM}=-0.169 * \mathrm{~V} 999+1.000 * \mathrm{D} 2$ & \\
Standard error & 0.047 & $\mathrm{ECON}=1.000 * \mathrm{D} 1$ \\
Robust test statistics & $-3.573^{*}$ & \\
Construct equation & $\mathrm{ECON}=0.080 * \mathrm{~V} 999+1.000 * \mathrm{D} 3$ & \\
Standard error & 0.052 & \\
Robust test statistics & 1.539 &
\end{tabular}

* Significant at $\mathrm{P}<0.05$ 
MAINT, respectively, $\mathrm{P}>0.05)$. This may have a simple explanation: poor openness of forests with forest roads (q2_13), unclear boundary lines (q2_14), or ignorance of parcel locations (q2_15) have nothing to do with forest management concepts. Nevertheless, model 21 fit the data significantly worse than model $2\left(\Delta \mathrm{CFI}=0.127\right.$ and $\Delta \mathrm{S}-\mathrm{B} \chi^{2}=7636$ at $\mathrm{df}=433, \mathrm{P}<0.01$, Table $1)$, confirming that the correlations between the representations of forest management and cutting constraints do not improve the understanding of harvesting behavior of private forest owners.

\section{DISCUSSION}

\section{Forest owner representation of forest management}

We have shed light on social representations of forest management in the first-ever quantitative national study of forest management conceptualization among private forest owners in Europe. We confirmed the existence of three representations of forest management, greatly resembling the forest owner concepts elicited by Steiner Davis and Fly (2010) in Tennessee. The EM concept may be similar to Steiner Davis and Fly's (2010:325) concept of "creating and enhancing forest habitat," a comparison could be drawn between the ECON concept and "making money," and the MAINT concept appears to closely resemble the "property maintenance" concept. The maintenance-centered concept is the most adopted concept by private forest owners in both studies.

The result that the owners who believe they are inefficient do not consider the maintenance of their properties as important as those who believe they are efficient and that such owners do not have a strong ecosystem-centered perception of forest management indicates that the perception of being inefficient is more prevalent among owners who mostly favor timber amenities but who are frustrated by the inability to extract as much as they wish to. We may conclude that forest owner perception of resource efficiency is similar to the traditional notion of economic efficiency.

However, our empirical findings on the consequences of forest management representations contrast those of other studies, most of which are from the United States. Erickson et al. (2002:108) concluded that private forest owners prefer no active management and to "let nature take its course." Our results show that underuse of wood resources in Slovenia is mostly because of biophysical constraints, and not to the general belief that "logging is worse than nonmanagement for the environment," which is said to be a consequence of a "deep-seated philosophical objection to harvesting" (Berlik et al. 2002:1564). Lawrence and Dandy (2014) concluded that the prevalent belief of private forest owners regarding the appropriate forest management in the United Kingdom is "nonintervention" and that this concept is to be blamed for underuse of forest resources. However, because Lawrence and Dandy (2014) built their review mostly on "grey literature" and did not provide statistical evidence for such a conclusion themselves, we cannot judge whether the difference between our results and theirs is because of the different social context of the studies and thus substantive; is because of different research methodologies, i.e., rapid evidence assessment versus structural equation modeling; or should be interpreted in light of the general discrepancy between the elicited mental constructions and actual behavior of an interviewee in a given situation (e.g., Lynam et al. 2012).
Leaving nonsubstantive explanations aside, we first point to differences in the historical dimension of forestland ownership in different parts of Europe, and the United States as well, particularly to the changing pattern of ownership. Lawrence and Dandy (2014) noted a wide cultural gap between farming and forestry in the United Kingdom, which is clearly not the case in Slovenia (Medved et al. 2010). Family farms were the dominant socioeconomic category of private forest ownership in Slovenia until 2005, when the share of family farms equaled the share of other forms of private ownership. Nevertheless, most of the owners still maintain a close relationship with their properties in terms of traditional forest management. Currently, $39 \%$ of private forest owners still run family farms (Medved et al. 2010), which are typically small in size and fragmented. Forests are not being planted. So far, the continuum of knowledge transfer on forest management to successors has been secured, which could be the major reason that the interviewed owners emphasized the maintenance of forest properties as the principal approach to forest management and that the MAINT concept overlapped substantially with the EM and ECON concepts.

However, generational knowledge transfer on traditional forest management may change in the future given the further increase of nonfarm ownership types. The elasticity between the prices of fossil fuels and prices of fuelwood (Härtl and Knoke 2014) may also contribute to faster mobilization of wood resources. Given our results that underuse of wood resources from private forests mostly relates to physical constraints, we believe that the increase in timber supply from private forests in Slovenia might be faster and greater compared to some Western European countries or the United States, where the growing number of nonresidential owners seeing the forest as part of an alternative lifestyle and environmental protectionism may be the principal constraint in the mobilization of wood resources from private forests.

Our empirical evidence that the nonintervention forest management concept is not a driver of the undersupply of wood resources from private forests seems to be contradictory to the conclusions of contemporary private forest owner research in Europe. However, rather than being contradictory, it is supplementary. None of the behavioral studies investigated the association between observed behavior and the fundamental understanding of concepts underlying forest management quantitatively, though they often refer to the theory of planned behavior (Ajzen 1991), which assumes a causal relation between beliefs and behavior. Some behavioral studies found the temporal instability of management objectives. For instance, Ingemarson et al. (2006) found that roughly $30 \%$ of owners believed they would change their objectives in the next 5 years, which seems to be in line with the suggestion of our structural equation models that the behavior in practice has only weak association with the representation of forest management, and that forest owner behavior might be more likely to change than researchers expected.

\section{Benefits and limitations of structural equation models in social representations studies}

A significant contribution of our study to contemporary research on forest owner conceptualization of forest management is in its methodological power. It is the first of its kind to be so rigorous in the relatively wide body of private forest ownership literature 
in Europe. Structural equation models allowed us to (1) keep the representations of forest management latent, (2) quantify the overlap between the representations by setting the correlation paths, and (3) measure latent concept means, which would otherwise be unmeasurable by conventional testing. By setting the correlation paths between the concepts, the substance is no longer a matter of labeling sufficiently for analytical interpretability, but it is also indicated through the correlations. Labels that have been used for forest owner conceptualization of forest management, such as nonintervention management, custodianship, guardianship (Lawrence and Dandy 2014), or "hands-off" management (Erickson et al. 2002), largely lack the statistical evidence on how much they overlap with each other and what their relation is to scientific concepts of forest management.

However, the presented approach also has its limitations. First, responses were constrained by finite lists of questions or variables. Respondents could not present their perception of forest management with their own words or phrases. Second, although structural equation modeling is a powerful multivariate technique, it cannot elicit all elements of mental models. The statistical theory underlying structural equation modeling is asymptotic, which means that we can elicit only the long-term and stable knowledge structures of a social group (see Fig. 1) but not the dimensions of the mental model related to specific circumstances or individuals (cf. Lynam et al. 2012). Third, structural equation models cannot handle qualitative data, which means that the quality of the results depends on the communality level between the variables, the degree of nonnormality of data, the estimation method, and particularly the sample size and features of the model of interest (Bentler 2006). More complex models turned out to require larger samples for the same degree of fit. Getting an acceptable fit for complex models may be problematic, which researchers should account for in their desire for a model that resembles complex human reasoning as closely as possible. Fortunately, parameter estimates, e.g., factor loadings and correlations, settle at the smallest sample sizes, and maximum likelihood estimation seems to be good even under violation of normality (Bentler 2006). This makes us confident that the content of forest management concepts we elicited, and the relationship between them, is valid, despite a somewhat mediocre model fit.

One of the major challenges in analyzing human-environment behavior is also the general discrepancy between the elicited mental models and actual behavior in a given situation. Some elements of the mental model relate to the situation in which individuals find themselves. Considering this, social scientists have raised some important concerns regarding consistently responding to questionnaire items on a basis other than that for which the items were designed, referred to as response style (Paulhus 1991). Response style can lead to biased models of social representations when elicited by quantitative methods without the detection of, and correction for, response styles (Billiet and McClendon 2000, Ficko and Bončina 2014). We found no acquiescence bias in our study (results available upon request).

\section{Challenges for natural resource policies}

Two of the concepts adopted by the owners in our study, i.e., the ECON concept and the EM concept, are incorporated in several natural resource management paradigms, which can be arranged along a commodity/noncommodity continuum (Brown and Harris 2000), by biocentric/anthropocentric value orientations (Vaske et al. 2001), or by a management intensity-silvicultural decisions matrix (Duncker et al. 2012).

The declarative care for forest property as an integral part of forest management can be found among human dimensions of almost all contemporary management paradigms. For example, forest ecosystem management "... must include consideration of the physical, emotional, mental, spiritual, social, cultural, and economic well-being of people and communities" (USDA Forest Service 1994:4 as cited in Kearney and Bradley 1998). However, traditional knowledge and the role of local forest owners are not explicitly mentioned in the EM concept (cf. Grumbine 1994, Yaffee 1999). Close-to-nature forestry, i.e., nature-based forestry, which is an indigenous derivative of the sustainable forestry concept in Central Europe where we conducted research (Johann 2006), sets the emulation of natural processes as the guiding principle (Duncker et al. 2012). Normatively, it incorporates the "traditional emotional attachment of people to forests and nature" (Pro Silva Europe 2012b:11) and "allows field foresters, forest owners and interested individuals to collaborate and exchange their experience" (Pro Silva Europe 2012a: article 1). However, both concepts strongly emphasize forests as ecosystems, not as social-ecological systems. The MAINT concept is most directly incorporated into the paradigm of community-based forest management applied mostly in developing countries, where forest management draws on the ingenuity and knowledge of local people (Swanson and Chapin 2009), but it seems to be widely missing in the policy initiatives of the developed countries from the Northern Hemisphere.

One of the top priorities in natural resource agendas in developed countries is still resource efficiency, though it has been redefined in different initiatives such as the green economy (OECD 2011), biobased economy (http://www.biobasedeconomy.eu), resourceefficient management (EC 2012, EREP 2013), or regenerative circular economy (http://www.ellenmacarthurfoundation.org). A common rationale behind these initiatives is that efficiency has to be upgraded, e.g., by using innovative technologies, to match the needs of society and its values, e.g., stakeholders, forest owners being just a part of them, in a changing world. Given our results, the question is whether appropriate forest management should always be articulated in a top-down manner by an open discourse. Would it not be, at least at the local scale, equally socially and ecologically effective to support traditional small-scale forest management that accounts for the ecological, economic, and social aspects of forests? Some examples (e.g., Schaich and Plieninger 2013) show that small-scale private forests in Central Europe have higher diversity of stand structures, store more carbon, and provide more habitat structures and diversity relevant for the conservation of typical and rare forest species than other forms of public ownership. We provide social psychological evidence on the significance of private forest owners for securing the ecological integrity of forests while maintaining the supply of the wood from forests.

\section{CONCLUSION}

We aimed to fill the gap in the understanding of social representations of forest management in Europe by studying how 
private forest owners conceptualize forest management and how they perceive resource efficiency. We have undertaken the firstever quantitative national study of forest management conceptualization among private forest owners in Europe that uses the theory of social representations and a hypothesis-testing approach. Our findings on the number of management concepts among nonindustrial private forest owners and their content are similar to those from the United States. Private forest owners consider maintenance of forests the main principle in managing the forest. However, the result that underuse of wood resources in Slovenia is not a consequence of the general belief that logging is worse than nonmanagement contrasts with the conclusions from other, although still scarce, studies on private forest owner representations that the passiveness of private forest owners is to be attributed to their nature-centered worldview. It is thought that forest owner management objectives and attitudes toward the forest have not been changing rapidly, but the theory of social representations could change this commonly accepted view. As private forest owners are becoming more and more urbanized in countries in which traditional forest ownership has persisted until recently, it is likely that they will become more responsive to societal changes in the future. A challenge for both researchers and policy makers will remain how to track these changes and especially how to develop management concepts that will meet the demands of rapidly changing societies.

Responses to this article can be read online at: http://www.ecologyandsociety.org/issues/responses. $\mathrm{php} / 7189$

\section{Acknowledgments:}

We thank the Pahernik Foundation for financial support in publishing the results.

\section{LITERATURE CITED}

Ajzen, I. 1991. The theory of planned behavior. Organizational Behavior and Human Decision Processes 50:179-211. http://dx. doi.org/10.1016/0749-5978(91)90020-T

Belin, D. L., D. B. Kittredge, T. H. Stevens, D. C. Dennis, C. M. Schweik, and B. J. Morzuch. 2005. Assessing private forest owner attitudes toward ecosystem-based management. Journal of Forestry 103(1):28-35.

Bentler, P. M. 1990. Comparative fit indexes in structural models. Psychological Bulletin 107:238-246. http://dx.doi. org/10.1037/0033-2909.107.2.238

Bentler, P. M. 2006. EQS 6 structural equations program manual. Multivariate Software, Encino, California, USA.

Berlik, M. M., D. B. Kittredge, and D. R. Foster. 2002. The illusion of preservation: a global environmental argument for the local production of natural resources. Journal of Biogeography 29:1557-1568. http://dx.doi.org/10.1046/j.1365-2699.2002.00768. $\underline{x}$

Billiet, J. B., and M. J. McClendon. 2000. Modeling acquiescence in measurement models for two balanced sets of items. Structural
Equation Modeling: A Multidisciplinary Journal 7:608-628. http:// dx.doi.org/10.1207/S15328007SEM0704_5

Brown, G., and C. C. Harris. 2000. The US Forest Service: whither the new resource management paradigm? Journal of Environmental Management 58:1-19. http://dx.doi.org/10.1006/ jema.1999.0310

Bryne, B. M. 2006. Structural equation modeling with EQS. Basic concepts, applications, and programming. Second edition. Lawrence Erlbaum Associates, Mahwah, New Jersey, USA.

Buijs, A. E., and B. H. M. Elands. 2013. Does expertise matter? An in-depth understanding of people's structure of thoughts on nature and its management implications. Biological Conservation 168:184-191. http://dx.doi.org/10.1016/j.biocon.2013.08.020

Buijs, A., T. Hovardas, H. Figari, P. Castro, P. Devine-Wright, A. Fischer, C. Mouro, and S. Selge. 2012. Understanding people's ideas on natural resource management: research on social representations of nature. Society \& Natural Resources: An International Journal 25:1167-1181. http://dx.doi. org/10.1080/08941920.2012.670369

Butler, B. J., Z. Ma, D. B. Kittredge, and P. Catanzaro. 2010. Social versus biological availability of woody biomass in the northern United States. Northern Journal of Applied Forestry 27 (4):151-159.

Cheung, G. W., and R. B. Rensvold. 2002. Evaluating goodnesof-fit indexes for testing measurement invariance. Structural Equation Modeling: A Multidisciplinary Journal 9:233-255. http:// dx.doi.org/10.1207/S15328007SEM0902_5

Commission of the European Communities. 2006. Communication from the Commission to the Council and the European Parliament on an EU forest action plan. $\{\operatorname{SEC}(2006) 748\}$. COM(2006) 302 Final. Commission of the European Communities, Brussels, Belgium. [online] URL: http://ec.europa.eu/agriculture/fore/ action plan/com en.pdf

Cronbach, L. J. 1951. Coefficient alpha and the internal structure of tests. Psychometrika 16:297-334. http://dx.doi.org/10.1007/ $\underline{\mathrm{BF} 02310555}$

Dhubháin, A. N., R. Cobanova, H. Karppinen, D. Mizaraite, E. Ritter, B. Slee, and S. Wall. 2007. The values and objectives of private forest owners and their influence on forestry behaviour: the implications for entrepreneurship. Small-Scale Forestry 6:347-357. http://dx.doi.org/10.1007/s11842-007-9030-2

Duncker, P. S., S. M. Barreiro, G. M. Hengeveld, T. Lind, W. L. Mason, S. Ambrozy, and H. Spiecker. 2012. Classification of forest management approaches: a new conceptual framework and its applicability to European forestry. Ecology and Society 17(4): 51. http://dx.doi.org/10.5751/ES-05262-170451

Erickson, D. L., R. L. Ryan, and R. De Young. 2002. Woodlots in the rural landscape: landowner motivations and management attitudes in a Michigan (USA) case study. Landscape and Urban Planning 58:101-112. http://dx.doi.org/10.1016/S0169-2046(01) 00213-4

European Commission (EC). 2012. Manifesto for a resourceefficient Europe. MEMO/12/989. EC, Brussels, Belgium. [online] URL: http://europa.eu/rapid/press-release_MEMO-12-989 en. $\underline{\text { htm }}$ 
European Parliament, Council of European Union. 2009. Directive 2009/28/EC of the European Parliament and of the Council of 23 April 2009 on the promotion of the use of energy from renewable sources and amending and subsequently repealing directives 2001/77/EC and 2003/30/EC. Official Journal of the European Union L 140:16-62.

European Resource Efficiency Platform (EREP). 2013. Action for a resource efficient Europe. Recommendations Adopted by the Platform on 17 June 2013. European Commission, Brussels, Belgium. [online] URL: http://ec.europa.eu/environment/ resource efficiency/documents/action_for_a resource efficient europe 170613.pdf

Ficko, A., and A. Boncina. 2013. Probabilistic typology of management decision making in private forest properties. Forest Policy and Economics 27:34-43. http://dx.doi.org/10.1016/j. forpol.2012.11.001

Ficko, A., and A. Bončina. 2014. Ensuring the validity of private forest owner typologies by controlling for response style bias and the robustness of statistical methods. Scandinavian Journal of Forest Research 29(Supplement 1):210-223. http://dx.doi. org/10.1080/02827581.2013.837194

Fischer, A., F. Langers, B. Bednar-Friedl, N. Geamana, and K. Skogen. 2011. Mental representations of animal and plant species in their social contexts: results from a survey across Europe. Journal of Environmental Psychology 31:118-128. http://dx.doi. org/10.1016/j.jenvp.2010.05.005

Food and Agriculture Organization of the United Nations (FAO). 2010. Global forest resources assessment 2010. Main report. FAO Forestry Paper 163. FAO, Rome, Italy. [online] URL: http://www. fao.org/docrep/013/i1757e/i1757e.pdf

Gold, S., A. Korotkov, and V. Sasse. 2006. The development of European forest resources, 1950 to 2000. Forest Policy and Economics 8:183-192. http://dx.doi.org/10.1016/j.forpol.2004.07.002

Grumbine, R. E. 1994. What is ecosystem management? Conservation Biology 8(1):27-38. http://dx.doi.org/10.1046/ j.1523-1739.1994.08010027.x

Hair, J. F., R. E. Anderson, R. L. Tatham, and W. C. Black. 1998. Multivariate data analysis. Fifth edition. Prentice-Hall International, London, UK.

Härtl, F., and T. Knoke. 2014. The influence of the oil price on timber supply. Forest Policy and Economics 39:32-42. http://dx. doi.org/10.1016/j.forpol.2013.11.001

Hogl, K., M. Pregernig, and G. Weiss. 2005. What is new about new forest owners? A typology of private forest ownership in Austria. Small-Scale Forestry 4:325-342.

Homer, P. M., and L. R. Kahle. 1988. A structural equation test of the value-attitude-behavior hierarchy. Journal of Personality and Social Psychology 54:638-646. http://dx.doi.org/10.1037/00$\underline{22-3514.54 .4 .638}$

Hovardas, T., and G. P. Stamou. 2006. Structural and narrative reconstruction of rural residents' representations of 'nature', 'wildlife', and 'landscape'. Biodiversity and Conservation 15:1745-1770. http://dx.doi.org/10.1007/s10531-004-5021-1
Hu, L., and P. M. Bentler. 1995. Evaluating model fit. Pages 76-99 in R. H. Hoyle, editor. Structural equation modeling. Concepts, issues, and applications. Sage, London, UK.

Hu, L., and P. M. Bentler. 1999. Cutoff criteria for fit indexes in covariance structure analysis: conventional criteria versus new alternatives. Structural Equation Modeling: A Multidisciplinary Journal 6:1-55. http://dx.doi.org/10.1080/10705519909540118

Ingemarson, F., A. Lindhagen, and L. Eriksson. 2006. A typology of small-scale private forest owners in Sweden. Scandinavian Journal of Forest Research 21:249-259. http://dx.doi. org/10.1080/02827580600662256

Johann, E. 2006. Historical development of nature-based forestry in Central Europe. Pages 1-17 in J. Diaci, editor. Nature-based forestry in Central Europe. Alternatives to industrial forestry and strict preservation. Biotechnical Faculty, Department of Forestry and Renewable Forest Resources, Ljubljana, Slovenia.

Jones, N. A., H. Ross, T. Lynam, P. Perez, and A. Leitch. 2011. Mental models: an interdisciplinary synthesis of theory and methods. Ecology and Society 16(1): 46. [online] URL: $\underline{\text { http:// }}$ www.ecologyandsociety.org/vol16/iss1/art46/

Kearney, A. R., and G. Bradley. 1998. Human dimensions of forest management: an empirical study of stakeholder perspectives. Urban Ecosystems 2:5-16. http://dx.doi.org/10.1023/ A:1009564812609

Kearney, A. R., G. Bradley, R. Kaplan, and S. Kaplan. 1999. Stakeholder perspectives on appropriate forest management in the Pacific Northwest. Forest Science 45(1):62-73.

Krejcie, R. V., and D. W. Morgan. 1970. Determining sample size for research activities. Educational and Psychological Measurement 30:607-610.

Lawrence A., and N. Dandy. 2014. Private landowners' approaches to planting and managing forests in the UK: what's the evidence? Land Use Policy 36:351-360. http://dx.doi. org/10.1016/j.landusepol.2013.09.002

Lynam, T., R. Mathevet, M. Etienne, S. Stone-Jovicich, A. Leitch, N. Jones, H. Ross, D. Du Toit, S. Pollard, H. Biggs, and P. Perez. 2012. Waypoints on a journey of discovery: mental models in human-environment interactions. Ecology and Society 17(3): 23. http://dx.doi.org/10.5751/ES-05118-170323

Mantau, U., U. Saal, K. Prins, F. Steierer, M. Lindner, H. Verkerk, J. Eggers, N. Leek, J. Oldenburger, A. Asikainen, and P. Anttila. 2010. EUwood: real potential for changes in growth and use of EU forests. Final Report. University of Hamburg, Centre of Wood Science, Hamburg, Germany. [online] URL: http://www.ab.gov. tr/files/ardb/evt/1_avrupa_birligi/1_9_politikalar/1_9 6_enerji_politikasi/ euwood final report.pdf

Mardia, K. V. 1970. Measures of multivariate skewness and kurtosis with applications. Biometrika 57:519-530. http://dx.doi. org/10.1093/biomet/57.3.519

Markowski-Lindsay, M., P. Catanzaro, D. Damery, D. B. Kittredge, B. J. Butler, and T. Stevens. 2012. Forest-based biomass supply in Massachusetts: how much is there and how much is available. Journal of Environmental Management 106:1-7. http:// dx.doi.org/10.1016/j.jenvman.2012.03.051 
Max, W., and D. E. Lehman. 1988. A behavioral model of timber supply. Journal of Environmental Economics and Management 15:71-86. http://dx.doi.org/10.1016/0095-0696(88)90029-0

McDonald, R. P., and M. R. Ho. 2002. Principles and practice in reporting structural equation analysis. Psychological Methods 7:64-82. http://dx.doi.org/10.1037/1082-989X.7.1.64

Medved, M., D. Matijašić, and R. Pisek. 2010. Private property conditions of Slovenian forests in 2010 (preliminary results). Pages 457-472 in M. Medved, editor. Small-scale forestry in a changing worlds: opportunities and challenges and the role of extension and technology transfer. Proceedings of the IUFRO conference (Bled, Slovenia, 6-12 June 2010). Slovenian Forestry Institute, Slovenia Forest Service, Ljubljana, Slovenia. [online] URL: http://www.iufro.org/download/file/5842/4585/30800-etat-bled10 pdf/

Moscovici, S. 2008. Psychoanalysis. Its image and its public. Polity, Cambridge, UK.

Nabuurs, G. J., A. Pussinen, J. van Brusselen, and M. J. Schelhaas. 2007. Future harvesting pressure on European forests. European Journal of Forest Research 126:391-400. http://dx.doi. org/10.1007/s10342-006-0158-y

Organisation for Economic Co-operation and Development (OECD). 2011. Towards green growth. OECD, Paris, France. [online] URL: http://www.oecd.org/greengrowth/48224539.pdf

Paulhus, D. L. 1991. Measurement and control of response bias. Pages 17-59 in J. P. Robinson, P. R. Shaver, and L. S. Wrightsman, editors. Measures of personality and social psychological attitudes. Volume 1. Academic, San Diego, California, USA. http://dx.doi. org/10.1016/B978-0-12-590241-0.50006-X

Pro Silva Europe. 2012a. Constitution PRO SILVA Association. Memorandum and articles of the association. Pro Silva Europe, Barr, France. [online] URL: $\underline{\text { htp://prosilvaeurope.files.wordpress. }}$ com/2013/01/pse-constitution.pdf

Pro Silva Europe. 2012b. Pro Silva principles. Pro Silva Europe, Barr, France. [online] URL: https://prosilvaeurope.files. wordpress.com/2013/01/ps-principles2012.pdf

Rickenbach, M. G., D. B. Kittredge, D. Dennis, and T. Stevens. 1998. Ecosystem management: capturing the concept for woodland owners. Journal of Forestry 96(4):18-24.

Satorra, A., and P. M. Bentler. 1988. Scaling considerations for chi-square statistics in covariance structure analysis (UCLA Statistic Series 2). University of California, Department of Psychology, Los Angeles, California, USA.

Satorra, A., and P. M. Bentler. 1994. Corrections to test statistics and standard errors in covariance structure analysis. Pages 399-419 in A. von Eye and C. C. Clogg, editors. Latent variables analysis: applications for developmental research. Sage, Thousand Oaks, California, USA.

Savalei, V., and P. M. Bentler. 2006. Structural equation modeling. Pages 330-364 in R. Grover, and M. Vriens, editors. The handbook of marketing research: uses, misuses, and future advances. Sage, Thousand Oaks, California, USA. http://dx.doi. org/10.4135/9781412973380.n17
Schaich, H., and T. Plieninger. 2013. Land ownership drives stand structure and carbon storage of deciduous temperate forests. Forest Ecology and Management 305:146-157. http://dx.doi. org/10.1016/j.foreco.2013.05.013

Schmithüsen, F., and F. Hirsch. 2010. Private forest ownership in Europe. Geneva Timber and Forest Study Papers 26. United Nations, Economic Commission for Europe, Geneva, Switzerland. [online] URL: http://www.unece.org/fileadmin/ DAM/timber/publications/SP-26.pdf

Sörbom, D. 1974. A general method for studying differences in factor means and factor structures between groups. British Journal of Mathematical and Statistical Psychology 27:229-239. http://dx.doi.org/10.1111/j.2044-8317.1974.tb00543.x

StatSoft. 2013. IBM SPSS Statistics. StatSoft, Tulsa, Oklahoma, USA.

Steiger, J. H. 1990. Some additional thoughts on components, factors, and factor indeterminacy. Multivariate Behavioral Research 25:41-45. http://dx.doi.org/10.1207/s15327906mbr2501_4

Steiner Davis, M. L. E., and J. M. Fly. 2010. Do you hear what I hear: better understanding how forest management is conceptualized and practiced by private forest landowners. Journal of Forestry 108:321-328.

Swanson, F. J., and F. S. Chapin III. 2009. Forest systems: living with long-term change. Pages 149-170 in F. S. Chapin III, G. P. Kofinas, and C. Folke, editors. Principles of ecosystem stewardship. Resilience-based natural resource management in a changing world. Springer Science, New York, New York, USA. http://dx.doi.org/10.1007/978-0-387-73033-2 7

Tavcar, J., and I. Winkler. 2005. Gozdnogospodarski vidiki izkorišèanja proizvodnih zmogljivosti zasebnih gozdov. Pages 169-187 in I. Winkler, editor. Prihodnost gospodarjenja z zasebnimi gozdovi v Sloveniji. Oddelek za gozdarstvo in obnovljive gozdne vire, Biotehniška fakulteta, Ljubljana, Slovenia.

Urquhart, J., P. Courtney, and B. Slee. 2012. Private woodland owners' perspectives on multifunctionality in English woodlands. Journal of Rural Studies 28:95-106. http://dx.doi.org/10.1016/j. jrurstud.2011.08.006

Vaske, J. J., M. P. Donnelly, D. R. Williams, and S. Jonker. 2001. Demographic influences on environmental value orientations and normative beliefs about national forest management. Society \& Natural Resources: An International Journal 14:761-776. http:// dx.doi.org/10.1080/089419201753210585

Verkerk, P. J., P. Anttila, J. Eggers, M. Lindner, and A. Asikainen. 2011. The realisable potential supply of woody biomass from forests in the European Union. Forest Ecology and Management 261:2007-2015. http://dx.doi.org/10.1016/j.foreco.2011.02.027

Veselic, Z., V. Mikulic, and R. Ogrizek. 2010. Lastniki gozdov o gozdarstvu, njihovem delu v gozdu in o delu Zavoda za gozdove Slovenije. Gozdarski vestnik 68:435-441. [online] URL: http:// www.dlib.si/details/URN:NBN:SI:DOC-CY23HJGU/?\&language= eng

Yaffee, S. L. 1999. Three faces of ecosystem management. Conservation Biology 13:713-725. http://dx.doi.org/10.1046/ j.1523-1739.1999.98127.x 
Appendix 1. Reasons for underuse or no cut (q2_1 to q2_17) used for the identification of cutting constraints, and statements defining forest management (q3_1 to q3_19) used to elicit forest owner representations of forest management ${ }^{\dagger}$. Mean scores and standard deviations are reported ( $n=103$ for Q2, $\mathrm{n}=754$ for Q3).

\begin{tabular}{|c|c|c|c|c|c|}
\hline \multicolumn{2}{|c|}{$\begin{array}{l}\text { Q2: Please rate the relevance of } \\
\text { each reason for underuse or no cut } \\
\text { with a 5-point Likert scale }{ }^{\ddagger} \text {. }\end{array}$} & Mean (S.D.) & \multicolumn{2}{|c|}{$\begin{array}{l}\text { Q3: Please indicate the level of agreement with } \\
\text { the following statements defining forest } \\
\text { management with a 5-point Likert scale. Forest } \\
\text { management is... }\end{array}$} & \multirow{2}{*}{$\begin{array}{l}\text { Mean } \\
\text { (S.D.) } \\
3.83(1.14)\end{array}$} \\
\hline$\overline{q 2 \_1}$ & I don & 3.12 & q3_1 & $\begin{array}{l}\text { The application of knowledge on how to } \\
\text { manage the forest ecosystem }\end{array}$ & \\
\hline q2_2 & $\begin{array}{l}\text { I have my forest as a } \\
\text { reserve }\end{array}$ & $3.25(1.54)$ & q3_2 & Capital management & $2.89(1.27)$ \\
\hline 2_3 & $\begin{array}{l}\text { Forest operations are too } \\
\text { costly }\end{array}$ & $3.41(1.48)$ & q3_3 & $\begin{array}{l}\text { Making decisions on what, when and how } \\
\text { a particular forest stand should be } \\
\text { managed }\end{array}$ & $.34(1.12)$ \\
\hline q2_4 & ices are too & $3.17(1.43)$ & q3_4 & A good business opportunity & $2.84(1.28)$ \\
\hline q2_5 & No cut is necessary & 2.70 & q3_5 & $\begin{array}{l}\text { Taking care o } \\
\text { disease preve }\end{array}$ & $4.12(1.09)$ \\
\hline q2_6 & $\begin{array}{l}\text { I don't r } \\
\text { wood }\end{array}$ & 2.62( & q3_6 & $\begin{array}{l}\text { orest, taking care of the } \\
\text { ders }\end{array}$ & $3.86(1.10)$ \\
\hline q2_7 & $\begin{array}{l}\text { I am not qualified for forest } \\
\text { work }\end{array}$ & $3.59(1.56)$ & q3_7 & restland for future & $4.07(1.08)$ \\
\hline q2_8 & $\begin{array}{l}\text { I am not properly equipped } \\
\text { to work in the forest }\end{array}$ & $3.52(1.58)$ & q3_8 & $\begin{array}{l}\text { Good opportunity to earn additional } \\
\text { money or to improve the family budget, } \\
\text { as any other side-business opportunity }\end{array}$ & $2.65(1.20)$ \\
\hline q2_9 & forest is & 3.82 & q3_9 & ity in the & $3.01(1.30)$ \\
\hline q2_10 & 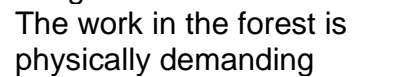 & 3.90 & q3_10 & $\begin{array}{l}\text { on of the work } \\
\text { ors }\end{array}$ & 18) \\
\hline q2 & $\begin{array}{l}\text { property is too } \\
\text { efficient }\end{array}$ & $(1.50)$ & & $\begin{array}{l}\text { ses in the forest } \\
\text { neration }\end{array}$ & 1.09) \\
\hline q2_12 & $\begin{array}{l}\text { I was not called to do the } \\
\text { cut }\end{array}$ & $2.82(1.50)$ & q3_12 & $\begin{array}{l}\text { using } \\
\text { operations }\end{array}$ & $3.75(1.22)$ \\
\hline q2_13 & $\begin{array}{l}\text { The openne } \\
\text { with forest } r\end{array}$ & 3.19 & q3_13 & $\begin{array}{l}\text { Ensuring regular flow of goods from my } \\
\text { forest which I need, such as fuel-wood }\end{array}$ & $4.02(1.18)$ \\
\hline q2_14 & $\begin{array}{l}\text { The boundary lines are } \\
\text { partly unclear }\end{array}$ & $2.57(1.50)$ & q3_14 & $\begin{array}{l}\text { Ensuring a clean and natural environment } \\
\text { in the neighborhoods }\end{array}$ & $4.27(1.02)$ \\
\hline q2_15 & $\begin{array}{l}\text { I don't know the exact } \\
\text { locations of my parcels }\end{array}$ & 2.53 & q3_15 & $\begin{array}{l}\text { Preserving large-diameter trees and } \\
\text { removing low-quality trees }\end{array}$ & $4.20(1.04)$ \\
\hline q2_16 & $\begin{array}{l}\text { I don't have time to manage } \\
\text { the forest }\end{array}$ & $2.75(1.46)$ & q3_16 & A source of subsidies & $2.44(1.35)$ \\
\hline \multirow[t]{3}{*}{ q2_17 } & $\begin{array}{l}\text { The allowable cut is below } \\
\text { my desire }\end{array}$ & $2.51(1.25)$ & q3_17 & $\begin{array}{l}\text { Keeping the forest beautiful exactly the } \\
\text { way I like it }\end{array}$ & $4.09(1.08)$ \\
\hline & & & q3_18 & $\begin{array}{l}\text { Making sure the forest is not left } \\
\text { neglected or messy }\end{array}$ & $4.22(1.00)$ \\
\hline & & & q3_19 & $\begin{array}{l}\text { Cutting large-diameter trees when they } \\
\text { are ready to be cut }\end{array}$ & $4.08(1.10)$ \\
\hline
\end{tabular}

\footnotetext{
${ }^{\mp}$ The measurement instrument may need to be adapted before used in other countries.

${ }^{\ddagger}$ The average inter-item correlation between the seventeen items was 0.26 , indicating sufficient heterogeneity of content. Internal consistency of the 17-item scale using Cronbach's (1951) alpha was 0.988 , which is excellent.

§Internal consistency of the 19-item scale estimated with Cronbach's (1951) alpha was good (0.885).
} 